\title{
ANALISIS KESALAHAN KONSEP SISWA DALAM MENYELESAIKAN SOAL ULANGAN MATEMATIKA DENGAN METODE NEWMAN
}

\author{
Melinda Rismawati ${ }^{1}$, Margareta Asnayani ${ }^{2}$ \\ ${ }^{1,2}$ Sekolah Tinggi Keguruan dan Ilmu Pendidikan Persada Khatulistiwa Sintang \\ e-mail : ${ }^{1}$ melris_1@yahoo.com, ${ }^{2}$ margaretaasnayani350@gmail.com
}

\begin{abstract}
This research to describe the concept errors in solving mathematical test with the Newman method in fourth grade. The approach used is a qualitative approach with a qualitative descriptive method in the form of case studies. The subjects of the study were the fourth grade students of 29 Sungai Puang Public Elementary School in 2018/2019 Academic Year totaling 14 people. Research instruments in the form of test questions, interview sheets, and documentation. The research data shows that the concept errors made by students in solving mathematical repetition problems of compound count operations are: a) Students make mistakes in reading commands in the questions (Reading); b) Students do not understand the problem (comprehension error); c) Errors of transformation (transformation) ie students have difficulty in changing questions into mathematical sentences; d) Errors of process skills (students 'skills) ie students make mistakes in arithmetic operations that result in calculation errors so that students' answers are wrong .; e) Errors of encoding (conclusions) ie students experience errors in changing the final result into contextual mathematical sentences or making conclusions. The most dominant mistake made by students is the process skill error because the students are less thorough and less skilled in counting. The role of the teacher in overcoming students' misconceptions namely: providing various activities in learning mathematics; use learning media, provide training so that students learn independently, use interesting learning models.
\end{abstract}

\section{Keyword: Fault, Concepts, Math Test, NEWMAN}

\begin{abstract}
Abstrak. Penelitian ini bertujuan untuk mendeskripsikan kesalahan konsep dalam menyelesaikan soal ulangan matematika dengan metode Newman pada siswa kelas IV. Pendekatan yang digunakan yaitu pendekatan kualitatif dengan metode deskriptif kualitatif berbentuk studi kasus. Subjek penelitian adalah siswa kelas IV Sekolah Dasar Negeri 29 Sungai Puang Tahun ajaran 2018/2019 berjumlah 14 orang. Instrumen penelitian berupa soal tes, lembar wawancara, dan dokumentasi. Data hasil penelitian menunjukkan bahwa kesalahan konsep yang dilakukan siswa dalam menyelesaikan soal ulangan matematika materi operasi hitung campuran yaitu: a)Siswa melakukan kesalahan dalam membaca perintah dalam soal (Reading); b) Siswa tidak memahami soal(kesalahan comprehension); c) Kesalahan transformation (transformasi) yaitu siswa kesulitan dalam mengubah soal ke dalam kalimat matematika.; d) Kesalahan process skill (keterampilan proses) yaitu siswa melakukan kesalahan dalam operasi hitung yang mengakibatkan kesalahan menghitung sehingga jawaban siswat salah.; e) Kesalahan encoding (kesimpulan) yaitu siswa mengalami kesalahan dalam mengubah hasil akhir ke dalam kalimat matematika kontekstual atau membuat kesimpulan. Kesalahan yang paling dominan dilakukan siswa adalah kesalahan keterampilan proses karena siswa kurang teliti dan kurang terampil dalam berhitung. Peranan guru dalam mengatasi kesalahan konsep siswa yaitu: menyediakan berbagai aktivitas dalam pembelajaran matematika; menggunakan media pembelajaran, memberikan latihan agar siswa belajar mandiri, menggunakan model pembelajaran yang menarik.
\end{abstract}

Kata Kunci: Kesalahan, Konsep, Ulangan Matematika, NEWMAN 


\section{PENDAHULUAN}

Matematika dikenal sebagai queen of knowlage dimana matematika merupakan ilmu dasar bagi segala bidang ilmu pengetahuan.Matematika merupakan salah satu ilmu yang sering digunakan dalam kehidupan sehari-hari.Banyak hal yang sering terjadi di kehidupan sekitar yang berhubungan dengan matematika. Hal ini sesuai dengan pernyataan Rismawati, dkk (2017: 466) yang menyatakan bahwa matematika memiliki 3 koneksi yaitu, koneksi antar ilmu matematika, koneksi matematika dan ilmu lain, serta koneksi antara matematika dan kehidupan sehari-hari.

Tercapai atau tidaknya tujuan pembelajaran matematika, salah satunya dapat dinilai dari keberhasilan siswa dalam memahami matematika dan memanfaatkan pemahaman ini untuk menyelesaikan persoalan-persoalan matematika maupun ilmuilmu yang lain. Lebih khusus lagi dalam pemecahan soal-soal matematika, siswa memerlukan kecakapan matematis (Mathematical Proficiency) diantaranya pemahaman konsep (conceptual understanding), Kelancaran prosedur (procedural fluency), strategic competence, kapasitas berpikir logis (adaptive reasoning), dan productive disposition (Afgani:2015 dan Rismawati \& Hutagaol: 2018)

Kecakapan atau kemahiran matematika yang diharapkan dapat tercapai dalam belajar matematika mulai dari SD/MI sampai SMA/MA menurut Farida (2016:290) adalah sebagai berikut: (1) menunjukkan pemahaman konsep matematika yang dipelajari yang ditunjukkan dengan mampu menjelaskan keterkaitan antara konsep dan mengaplikasikan konsep atau algoritma secara luwes, akurat, efisien, dan tepat dalam pemecahan masalah; (2) memiliki kemampuan mengkomunikasikan gagasan dengan simbol, tabel, grafik, atau diagram untuk memperjelas keadaan atau masalah; (3) menggunakan penalaran pada pola, sifat atau melakukan manipulasi matematika dalam membuat generalisasi, menyusun bukti, atau menjelaskan gagasan dan pernyataan matematika; (4) menunjukkan kemampuan strategi dalam membuat (merumuskan), menafsirkan, dan menyelesaikan model matematika dalam pemecahan masalah; (5) memiliki sikap menghargai kegunaan matematika dalam kehidupan.

Menyadari pentingnya peranan dan tujuan pembelajaran matematika seperti diuraikan di atas, maka sangatlah diharapkan agar siswa menguasai pelajaran matematika sesuai dengan tuntutan kurikulum. Namun tidak dapat dipungkiri bahwa hingga saat ini penguasaan siswa terhadap matematika relatif rendah. Hasil penelitian dari Heppinia \& Tiya (2015), Rismawati (2016) dan Rismawati \& Hutagaol 2018) menyimpulkan bahwa kendala yang dihadapi dalam pembelajaran matematika diantaranya adalah pemahaman siswa terhadap konsep yang dipelajari masih rendah, siswa kurang bisa mengkomunikasikan ide matematisnya dalam menyelesaikan masalah, siswa masih terbiasa menghafal rumus tanpa memahami konsep 
pada saat belajar matematika, siswa masih salah dalam menggunakan prosedur dalam memecahkan masalah matematika. Kesalahankesalahan yang dilakukan siswa umumnya ditemui pada saat pelaksanaan ulangan, ujian, atau dari tugas-tugas yang diberikan guru.

Salah satu kesalahan yang sering dialami siswa dalam menyelesaikan soal-soal matematika adalah adanya kesalahan konsep. Kesalahan konsep dalam matematika akan berakibat lemahnya penguasaan materi prasyarat sebelum melangkah ke materi selanjutnya. Kesalahan pada konsep dasar matematika akan menyulitkan penguasaan konsep matematika selanjutnya di kelas yang lebih tinggi karena konsep yang satu akan menjadi dasar untuk memahami konsep yang lain (Rismawati:2016). Kesalahan konsep adalah kesalahan siswa dalam menguasai konsep-konsep tertentu untuk menyelesaikan suatu masalah (Sennen, dkk; 2016: 256).

Siswa dikatakan mengalami kesalahan konsep jika siswa tidak mampu memahami simbol dan nilai tempat, kekeliruan dalam perhitungan, kekeliruan dalam penggunaan proses, tulisan yang tidak dapat dibaca, dan kesalahan menginterpretasikan jawaban kalimat matematika. Indikator lemahnya pemahaman konsep dasar siswa antara lain kesalahan dalam memahami pertanyaan soal sehingga dalam proses pengerjaannya salah, kesalahan dalam mengerjakan soal karena siswa lupa dalam proses pengerjaan, dan tidak teliti dalam mengerjakan soal.

Berdasarkan informasi yang didapatkan setelah melakukan observasi di Sekolah Dasar
Negeri 29 Sungai Puang pada tanggal 12 Maret 2018 yaitu dengan melakukan wawancara dengan guru menyatakan bahwa kemampuan siswa dalam memahami konsep matematika sangat kurang. Hal ini terlihat ketika siswa diberikan soal-soal pemahaman matematika, siswa masih sering tertukar menggunakan rumus-rumus dalam perhitungan sederhana dan tidak dapat menghubungkan antara konsep yang satu dengan konsep yang lain.

Berdasarkan laporan hasil ulangan harian, tengah semester dan ulangan akhir semester siswa di kelas IV SD Negeri 29 Sungai Puang Tahun Ajaran 2017/2018, ditemukan siswa yang mendapat nilai ulangan matematika sangat rendah sekali, yaitu 10 . Disisi lain, ada siswa yang mendapat nilai yang sudah lebih dari KKM. Hasil tersebut menunjukkan bahwa terdapat kesenjangan antara nilai tertinggi dan terendah yang diperoleh siswa dalam ulangan tengah semester dan ulangan umum SD Kelas IV untuk mata pelajaran matematika.

Mencermati masalah tersebut, maka dalam pembelajaran guru perlumenganalisis kesalahan siswa untuk dapat memahami kesalahan siswa sehingga akan mampu meningkatkan pemahaman dan keterampilan siswa dalam menyelesaikan masalah matematika. Kajian yang dapat dilakukan terhadap hasil pekerjaan siswa dalam mengerjakan soal ulangan matematika dapat dilakukan dengan menggunakan prosedur tertentu, salah satunya adalah prosedur NEWMAN. 
NEWMAN menerbitkan data berdasarkan sistem yang di kembangkan untuk menganalisis kesalahan yang dibuat pada tugas-tugas tertulis. Prakitipong \& Nakamura (Amini dan Yunianta, 2018:4) menyatakan tahapan analisis kesalahan yaitu membaca masalah (reading), memahami masalah (comprehension), transformasi masalah (transformation), keterampilan proses (process skill), dan penulisan jawaban akhir (encoding).

Berdasarkan masalah tersebut peneliti melakukan penelitian studi kasusuntuk menganalisis kesalahan konsep dalam menyelesaikan soal ulangan matematika dengan metode NEWMAN pada siswa kelas IV SD negeri 29 Sungai Puang tahun ajaran 2018/2019”.

Fokus masalah dalam penelitian ini adalah sebagai berikut : (1) Kesalahan konsep dalam menyelesaikan soal ulangan matematika dengan metode Newman pada siswa kelas IV Sekolah Dasar Negeri 29 Sungai Puang Tahun ajaran 2018/2019. (2) Jenis kesalahan konsep yang dilakukan siswa yang paling dominan dalam menyelesaikan soal ulangan matematika dengan metode Newman pada siswa Kelas IV SD Negeri 29 Sungai Puang Tahun ajaran 2018/2019. (3) Peranan guru dalam mengatasi kesalahan konsep dalam menyelesaikan soal ulangan matematika berdasarkan metode Newman pada siswa di kelas IV SD Negeri 29 Sungai Puang Tahun ajaran 2018/2019.

Adapun tujuan penelitian ini adalah sebagai berikut: (1) mendeskripsikan kesalahan konsep dalam menyelesaikan soal ulangan matematika dengan metode Newman pada siswa kelas IV SD Negeri 29 Sungai

Puang Tahun ajaran 2018/2019,

mendeskripsikan jenis kesalahan konsep yang dilakukan siswa yang paling dominan dalam menyelesaikan soal ulangan matematika dengan metode Newman pada siswa Kelas IV SD Negeri 29 Sungai Puang Tahun Ajaran 2018/2019, (3) mendeskripsikan peranan guru dalam mengatasi kesalahan konsep siswa dalam menyelesaikan soal ulangan matematika dengan metode Newman pada siswa kelas IV SD Negeri 29 Sungai Puang Tahun Ajaran 2018/2019.

\section{METODE}

Metode yang digunakan dalam penelitian ini adalah metode kualitatif deskriptif. Penelitian deskriptif berusaha mendeskripsikan dan menginterprestasi apa yang ada (bisa mengenai kondisi atau hubungan yang ada, pendapat yang sedang tumbuh, proses yang sedang berlangsung, akibat atau efek yang terjadi atau kecenderungan yang tengah berkembang (Mukhtar, 2013:26).

Analisis deskriptif dalam penelitian ini digunakan untuk menganalisis dan mendeskripsikan kesalahan konsep siswa dan faktor-faktor yang mempengaruhi kesalahan konsep siswa dalam menyelesaikan soal ulangan matematika pada materi operasi hitung campuran di kelas IV Sekolah Dasar Negeri 29 Sungai Puang Tahun ajaran 2018/2019, Kecamatan Ketungau Tengah.

Bentuk penelitian yang digunakan dalam penelitian ini adalah studi kasus dimana peneliti berusaha untuk mengetahui bagaimana 
kesalahan konsep yang dilakukan siswa dalam menyelesaikan soal ulangan matematika di kelas IV Sekolah Dasar Negeri 29 Sungai Puang Tahun ajaran 2018/2019.Peneliti mengumpulkan data dan mendeskripsikan setiap permasalahan yang dihadapi oleh siswa berkaitan dengan kesalahan konsep yang dilakukan dalam menyelesaikan soal ulangan matematika yang disesuaikan dengan keadaan sebenarnya yang terjadi di lokasi penelitian tersebut.

Subjek dalam penelitian ini adalah siswa kelas IV Sekolah Dasar Negeri 29 Sungai Puang Tahun Ajaran 2018/2019 yang berjumlah 14 orang siswa. Subyek wawancara yang telah ditetapkan oleh peneliti terdiri atas 3 orang siswa yaitu siswa yang nilai matematikanya tinggi, sedang, dan rendah. Subjek penelitian ini nantinya akan diberikan kode A1, A2, dan A3.

Teknik pengumpulan data yang peneliti gunakan dalam penelitian ini meliputi teknik pengukuran, teknik komunikasi langsung dan teknik dokumentasi. Tes dalam penelitian ini memuat soal ulangan harian matematika dengan bentuk soal yang dipilih adalah bentuk uraian dengan jumlah soal 6 soal yang akan dikerjakan oleh semua siswa kelas IV SD Negeri 29 Sungai Puang Tahun ajaran 2018/2019. Pedoman wawancara yang digunakan hanya berupa garis-garis besar permasalahan yang akan ditanyakan.

Didalam penelitian ini digunakan analisis kualitatif sesuai dengan tujuannya untuk membuat deskriptif secara sistematis, faktual dan akurat mengenai fakta-fakta serta hubungan antara fenomena yang diteliti. Menurut Creswell (2009: 162), peneliti sebagai instrumen kunci (researcher as key instrument), para peneliti kualitatif mengumpulkan sendiri data melalui pengadaan tes, dokumentasi, wawancara dengan partisipan. Menurut Miles and Huberman dalam Sugiyono (2016:247), analisis data kualitatif dilakukan secara interaktif melalui proses data reduction, data display, dan verification.

\section{HASIL DAN PEMBAHASAN}

\section{a. Kesalahan Membaca}

Hasil analisis data menunjukkan bahwa rata-rata persentase kesalahan membaca soal (reading) sebesar $11,86 \%$. Hal ini menunjukkan bahwa kategori kesalahan membaca soal (reading) tergolong kecil. Pada kategori kesalahan membaca soal (reading) siswa yang mengalami kesulitan dalam memaknai kalimat dengan tepat, kesalahan dalam menentukan kata kunci dalam soal dan kesalahan dalam mengilustrasikan soal ke dalam kalimat matematika yang diharapkan.

Hasil penelitian ini sejalan dengan penelitian Arifani dkk., dalam Fatahillah, dkk (2017:545) menyatakan bahwa kesalahan membaca terjadi karena siswa salah dalam membaca soal sehingga saat mengerjakan soal siswa tidak dapat menggunakan informasi yang terdapat dalam soal dan membuat jawaban siswa tidak sesuai dengan 
maksud soal.

$$
\text { Dapat disimpulkan bahwa }
$$
penyebab siswa dalam melakukan kesalahan pada tahap membaca yaitu: 1) Siswa yang terburu-buru dalam membaca soal; 2) siswa yang tidak membaca seluruh informasi yang ada pada soal; 3) tidak memahami atau tidak dapat menemukan kata kunci yang ada pada soal; dan 4) kemampuan menganalisa soal siswa yang rendah.

\section{b. Kesalahan memahami}

Pada tahap ini, siswa sulit memahami soal diantaranya siswa melakukan kesalahan pada saat menuliskan apa yang diketahui dan apa yang ditanyakan. Persentase kesalahan memahami (comprehension) sebesar $25,05 \%$. Hal ini sesuai dengan pendapat Amini dan Yuanita (2018:25) yang menyatakan bahwa kesalahan dalam memahami soal terjadi jika siswa salah menentukan hal yang diketahui, ditayangkan, dan tidak dapat menuliskan apa yang dikehendaki.

\section{c. Kesalahan transformasi}

Presentase kesalahan transformasi (transformation) $\quad$ sebesar $\quad 20,18 \%$. Kesalahan transformasi masalah (transformation) yaitu suatu kesalahan dimana siswa tidak dapat mengidentifikasi operasi atau metode yang diperlukan untuk menyelesaikan soal. Damayanti, dkk., (2017:6), transformation error (kesalahan mentransformasi) yang dilakukan siswa adalah kurang tepat saat merubah soal menjadi model matematika, salah saat merubah soal menjadi model matematika, tidak dapat merubah soal ke dalam bentuk model matematika, tidak mengerti metode yang digunakan untuk menjawab soal (macet). Kesalahan transformasi juga terjadi karena mahasiswa kurang cakap dalam mengkomunikasikan ide matematisnya. Mahasiswa hanya bisa menuliskan proses penyelesaian masalah pada kertas, tetapi kurang luwes dalam menjelaskan/ mengomunikasikan ide-ide matematisnya di depan kelas untuk mengerjakan soal tersebut. Hal ini sesuai dengan hasil penelitian dari Rismawati (2016) yang menyatakan bahwa siswa kurang dapat mengkomunikasikan gagasan dengan bahasa matematika.

\section{d. Kesalahan keterampilan proses}

Presentase

kesalahan keterampilan proses (process skill) sebesar 29,68\%. Hal ini menunjukkan bahwa kesalahan keterampilan proses tergolong cukup tinggi. Pada tahap ini banyak siswa melakukan kesalahan konsep dan kesalahan komputasi dan tidak sedikit siswa yang tidak melanjutkanprosedur penyelesaian/macet. Siswa juga salah menggunakan proses penyelesaian yang tidak jelas langkahnya, akibatnya perhitungan yang dilakukan salah. Dharma, dkk., (2016: 9) menyatakan pada kategori kesalahan keterampilan proses masih banyak siswa yang mengalami kesulitan dalam melakukan perhitungan atau komputasi 
dan tidak melanjutkan perhitungan.

\section{e. Kesalahan Penulisan Jawaban Akhir}

Presentase kesalahan penulisan jawaban akhir (encoding) sebesar 13,04\%. Hal ini menunjukkan bahwa kategori kesalahan penulisan jawaban akhir (encoding) tergolong rendah.Pada tahap encoding siswa tidak menuliskan jawaban akhir dan menuliskan jawaban akhir yang tidak sesuai dengan konteks soal. Penyebab kesalahan penulisan jawaban akhir dari hasil wawancara bahwa siswa mengalami kesulitan ketika menuliskan jawaban akhir atau satuan yang sesuai dengan permintaan soal disebabkan kurang teliti dan tergesa-gesa dalam mengerjakan soal, kemampuan siswa yang rendah dalam menentukan solusi dari permasalahan matematika, keterampilan hitung siswa yang lemah, siswa tidak terbiasa mengecek atau memeriksa hasil yang diperoleh, dan siswa tidak terbiasa menulis kesimpulan.

Kesalahan pada tahap encoding terjadi saat siswa salah atau tidak menuliskan kesimpulan sebagai akhir dari soal, hal ini terjadi karena siswa tidak teliti dan tidak mengecek kembali jawaban akhir sebelum dikumpulkan (Mariyati, dkk., 2018:345). Sebagaimana hasil penelitian Permadi dan Irawan (2016:176) yang menyatakan bahwa kesalahan paling banyak ditemukan pada kategori encoding karena kekurangtelitian subjek sehingga tidak memeriksa kembali hasil pekerjaannya.
Kesalahan yang paling banyak dilakukan siswa dalam menyelesaikan soal ulangan matematika materi operasi hitung campuran yaitu kesalahan pada tahap keterampilan proses (process skill) dengan besar presentase kesalahan 29,68\%. Kesalahan konsep siswa tersebut terjadi karena siswa kurang memahami langkah-langkah dan prosedur yang diperlukan untuk menyelesaikan operasi secara tepat.

Siswa yang dikategorikan tidak mampu menyelesaikan operasi hitung adalah siswa yang melakukan kesalahan dalam melakukan perhitungan pada suatu langkah penyelesaian soal.Siswa tidak cermat atau teliti dalam melakukan perhitungan seperti kesalahan dalam melakukan penjumlahan, pengurangan, dan perkalian. Dalam menyelesaikan soal matematika siswa seharusnya melakukannya melalui langkah-langkah penyelesaian seperti yang dikemukakan oleh Rahayu (2016:7), yaitu memahami soal, membuat bentuk matematika, melakukan komputasi, dan menarik kesimpulan. Selain itu, siswa juga harus memeriksa kembali langkah-langkah dan hasil penyelesaiannya.

Peranan guru untuk menanggulangi kesalahan konsep siswa, yaitu memberikan perhatian kepada siswa yang mengalami kesulitan dalam belajar, menggunakan media pembelajaran, memberikan tugas dan latihan agar siswa mau belajar secara 
mandiri, mengarahkan siswa belajar dalam kelompok, menggunakan model pembelajaran yang menarik dan memberikan penghargaan kepada siswa sehingga siswa merasa senang dan termotivasi dalam belajar. Guru juga menggabungkan materi yang diajarkan tiap hari di sekitar siswa agar siswa mudah memahami konsep yang diajarkan.

Hal ini sesuai dengan pendapat Budiyanto dalam Senen, dkk., (2016:134) yang menyatakan memberikan peningkatan motivasi belajar kepada siswa secara konsisten dan kontinu, merupakan suatu usaha yang harus dilakukan guru kepada siswanya agar siswanya dapat termotivasi untuk lebih giat dalam belajar dan mengikuti pelajaran. Pemberian motivasi belajar saat les tambahan berlangsung guna memberikan dorongan semangat bagi siswa berkesulitan belajar untuk selalu belajar dengan sungguh-sungguh baik di sekolah maupun di rumah.

\section{SIMPULAN (PENUTUP)}

Berdasarkan paparan data, hasil penelitian, dan pembahasan penelitian yang telah diuraikan maka diperoleh kesimpulan bahwa kesalahan konsep dalam menyelesaikan soal ulangan matematika dengan metode Newman pada siswa kelas IV Sekolah Dasar Negeri 29 Sungai Puang Tahun Ajaran 2018/2019 meliputi: a) Kesalahan reading (membaca) yaitu siswa masih mengalami kesalahan dalam membaca perintah yang dituliskan dalam soal; b) Kesalahan comprehension (memahami) yaitu siswa tidak memahami soal yang diberikan yang ditunjukkan dengan siswa salah mengartikan maksud dari soal yang diberikan.; c) Kesalahan transformation (transformasi) yaitu siswa kesulitan dalam mengubah soal ke dalam kalimat matematika; d) Kesalahan process skill (keterampilan proses) yaitu siswa melakukan kesalahan dalam operasi hitung yang mengakibatkan salah hitung sehingga jawaban siswa tersebut salah.; e) Kesalahan encoding (kesimpulan) yaitu siswa mengalami kesalahan dalam mengubah hasil ke dalam kalimat matematika kontekstual atau membuat kesimpulan. Jenis-jenis kesalahannya yaitu kesalahan penulisan jawaban akhir, kesalahan dalam menggunakan notasi, dan tidak menuliskan variabel/satuan.

Kesalahan konsep yang paling dominan dilakukan siswa yaitu kesalahan pada keterampilan proses yang disebabkan karena siswa salah dalam perhitungan atau komputasi. Kesalahan konsep pada tahap keterampilan proses terjadi karena siswa kurang memahami langkah-langkah dan prosedur yang diperlukan untuk menyelesaikan operasi secara tepat. Peranan guru untuk mengatasi kesalahan konsep siswa, yaitu memberikan perhatian kepada siswa yang mengalami kesulitan dalam belajar, menggunakan media pembelajaran, memberikan tugas dan latihan agar siswa mau belajar secara mandiri, mengarahkan siswa belajar dalam kelompok, menggunakan model pembelajaran yang menarik dan memberikan penghargaan kepada siswa sehingga siswa merasa senang dan 
termotivasi dalam belajar. Guru juga menggabungkan materi yang diajarkan tiap hari di sekitar siswa agar siswa mudah memahami konsep yang diajarkan.

Saran pada peneliti untuk penelitian selanjutnya adalah: 1) Penggunaan metode Newman untuk menganalisis kesalahan siswa dalam mengerjakan soal matematika merupakan sebuah strategi pembelajaran yang menggali kesalahan-kesalahan siswa, 2) Peneliti selanjutnya mampu memunculkan ideide atau gagasan kreatif yang dapat menjadi sebuah strategi belajar dan model pembelajaran baru dalam pembelajaran matematika yang menyenangkan.

\section{DAFTAR RUJUKAN}

Afgani,D.J. 2015. Analisis Kurikulum Matematika. Universitas Terbuka: Banten.

Amini.S. dan Yunianta, H. 2018.Analisis Kesalahan Newman Dalam Menyelesaikan Soal Cerita Aritmatika Sosial dan Scaffolding Bagi Kelas VII SMP. Jurnal Pendidikan Matematika, 3(1):1-27.

Creswell,J.W. 2009. Research Design Qualitative, Quantitative, and Mixed Methods Approaches Third Edition. SAGE: LA.

Damayanti,W.N.,

Mayangsari,S.N. Mahardhika,L.T. 2017. Analisis Kesalahan Siswa Dalam Pemahaman Konsep Operasi Hitung Pada Pecahan. Jurnal Ilmiah Edutic, 4(1):1-7.

Dharma,I.Md., Suarjana,I.Md., Suartama,I.Kd. 2016. Analisis Kemampuan Menyelesaikan Soal Cerita Pada Siswa Kelas IV Tahun ajaran 2015/2016 Di SD Negeri 1 Banjar Bali. e-Journal PGSD Universitas
Pendidikan Ganesha Jurusan PGSD, 4(1):1-10.

Farida, A. 2016. Analisis Miskonsepsi Siswa Tehadap Simbol dan Istilah Matematika Pada Konsep Hubungan Bangun Datar Segiempat Melalui Permainan Dengan Alat Peraga Di SD Muhammadiyah 1 Surakarta. Prosiding Konferensi Nasional Penelitian Matematika Dan Pembelajaran (KNPMP) ISNN: 2502-6526 Hal 286-295

Fatahillah,A., Wati,Y.F., Susanto. 2017. Analisis Kesalahan Siswa Dalam Menyelesaikan Soal Cerita Matematika Berdasarkan Tahapan Newman Beserta Bentuk Scaffolding Yang Diberikan. Jurnal Kadikma, 8(1): 40-51.

Heppinia, M. dan Tiya, K. 2015. Analisis Kesalahan Siswa Kelas VII SMP Negeri 1 Wawotobi Dalam Menyelesaikan Soal-Soal Pecahan. Jurnal Penelitian Pendidikan Matematika, 3(3):27-65.

Mariyati, Y., Riyadi. dan Wardi, M. 2018. Analisis Kesalahan Siswa Kelas VI SDN 2 Tamansari TahunPelajaran 2015/2016 Dalam Menyelesaikan Soal Matematika UASBN 2014/2015.Jurnal Elementary, 1(1):342-369.

Mukhtar. 2013. Metode Praktis Penelitian Deskriptif Kualitatif. Jakarta: Referensi (GP Press Group).

Permadi dan Irawan. 2016. Memahamkan Konsep Pecahan Pada Siswa Kelas IV SDN Sumberejo 03 Kabupaten Malang. Jurnal Pendidikan: Teori, Penelitian, dan Pengembangan, 1(9):173-178.

Rahayu, S. 2016. Analisis Kesalahan Siswa Dalam Menyelesaikan Soal-Soal Kesebangunan. Jurnal e-DuMath, 2(2):1-9. 
Rismawati, M. 2016. Struktur Koneksi Matematis Siswa Kelas X pada Materi Sistem Persamaan Linier. Tesis tidak diterbitkan. Universitas Negeri Malang: Malang.

Rismawati, M. 2016. Mengembangkan Peran Matematika Sebagai Alat Berpikir Ilmiah Melalui Pembelajaran Lesson Study.Jurnal Vox Education, 7(2): 203- 215.

Rismawati, M. \& Hutagaol, A.S.R. 2018. Analisis Kemampuan Pemahaman Konsep Matematika Mahasiswa PGSD STKIP Persada Khatulistiwa Sintang.Jurnal Pendidikan Dasar PerKhasa , 4(1): 91-105.
Rismawati, M., Edi, B.I., Hery, S. 2017. Struktur Koneksi Matematis Siswa Kelas X Pada Materi Sistem Persamaan Linier Dua Variabel. Jurnal Pendidikan: Teori, Penelitian, dan Pengembangan, 2(4): 465-469.

Sennen, E. Ndiung. S. Supardi.K. 2016. Analisis Kesalahan Siswa Sekolah Dasar Dalam Menyelesaikan SoalSoal Matematika Yang Terkategori Sulit Pada UASBN. Jurnal Pendidikan dan Kebudayaan Missio, 8(2): 88-137.

Sugiyono. 2016. Memahami Penelitian Kualitatif. Bandung: Alfabeta. 